\title{
Determinants Of Crime In Virginia: An Empirical Analysis
}

Abdiweli M. Ali, Ph.D., Niagara University, USA

Willam Peek, Ph.D., Niagara University, USA

\begin{abstract}
This paper is an empirical analysis of the determinants of crime in Virginia. Over a dozen explanatory variables that current literature suggests as important determinants of crime are collected. The data is from 1970 to 2000. These include economic, fiscal, demographic, political, and social variables. The regression results indicate that crime is a function of a number of variables, which supports the predictions of the empirical literature on crime.
\end{abstract}

\section{INTRODUCTION}

C $\mathrm{n}$ recent years few issues have taken up more headlines than crime and violence. Crime statistics in Virginia has increased eighty percent from 1980 to 2000 in the rates of reported crime. All crime categories have increased, but in recent years some crimes have increased more than others; crimes that have been affected by economic and life style changes, notably offenses like household burglary. Changes in social structure, economics, demographics, and politics can all affect the crime rate. Some researchers suggest that the incidence of crime has not changed, however, people has been encouraged to report crimes, either by specific campaigns such as those with respect to domestic violence, or because of the increased vigilance of insurance companies, which require victims of crime to report the incident to police as a condition of policy.

This paper is an empirical analysis of the determinants of crime in Virginia. Over a dozen explanatory variables that current literature suggests as important determinants of crime are collected. The data is from 1970 to 2000. These include economic, fiscal, demographic, political, and social variables. The regression results indicate that crime is a function of a number of variables, which supports the predictions of the empirical literature on crime. However, the results also suggest that not all factors are equally important in explaining crime rates. Variables such as poverty rate, gross state product, alcohol consumption per capita, expenditure on education per pupil, the number of people on welfare, and the number of children born out of wedlock are found to be well-behaved determinants of crime in Virginia. While these are by no means the only determinants of crime and other factors may also contribute to the rate of increase or decrease of crime in Virginia, these variables are robust to changes in model specifications while most of the other variables are fragile when other explanatory variables are included in the regression equation. The paper tries to contribute to the policy debates on the issues of crime and incarceration. The relevant analytical problem is to understand what determines crime, and then develop policies and programs that will reduce the incidence of crime and criminal activity. As long as the causes of crime are not clearly grasped, it will be difficult to discern any useful prognosis from the reported statistics. The paper is organized as follows. Section 2 is a review of the literature on determinants of crime. The literature review sheds some light on why certain variables are included in the regression equations. Section 3 evaluates the empirical results of the determinants of crime, while section 4 concludes and offers suggestions for further research.

\section{AN OVERVIEW OF THE DETERMINANTS OF CRIME}

\section{A. Crime and Demographic Variables}

One of the demographic variables the current literature on crime finds relevant as an important determinant of crime is population density. The current literature suggests that if the percent of the population who commits crime and goes to prison stays constant, the larger the population in any given area, the more people would commit 
crime. Therefore, the percent of the population who commits crime increases as the population gets larger. Subculture theory and choice theory explain the increase in the percent of the population who commit crime by attributing it to an increase in subculture groups and a decrease in the likelihood that a given offender will be singled out for his actions in densely populated areas (Braithwaite 1989, Cohen \& Machalek 1988). As Grimes \& Rogers (1999) suggested, larger populations in a given area will generate crime on a larger scale.

Another demographic variable commonly touted as a strong determinant of crime is the percent of total population that is black. About two-thirds of Virginia prison population is black. Cultural conflict theorists argue that law enforcement officials are more likely to incarcerate minorities than others. Previous research done on policing shows that cities with greater percentage of blacks have either more police per capita (Jacobs 1979), or spend more for police protection (Jackson 1989). Joubert, Picou, and McIntosh (1981) reported that the percentage of the population comprised by blacks was the most important determinant of crime and imprisonment rates. Similarly, Arvanites (1993) investigated the effect of race on crime and imprisonment in 1980 and 1988. Using state-level data Arvanites reported that percent black was the strongest predictor of crime and incarceration rates in both years among a host of other predictor variables. Carroll and Doubet (1983) have criticized the specification of these models. Using violent crime instead of the total crime rate, and including region and education variables, they reported that percent black has no effect on crime and incarceration.

Another demographic variable that the current literature deems as an important determinant of crime is the crime prone age groups; that is those that are age 15 to 24 . Criminal activity decreases with age and it is quite plausible that crime rates maybe influenced by the proportion of young people in each state. Hence, the percent of population comprised by the crime prone ages (15-24) will be included in the empirical analysis.

\section{B. Fiscal and Economic Variables}

The economic and fiscal variables that are standard in the literature and are commonly believed to be important determinants of crime include poverty rate and unemployment. Higher rates of unemployment and a greater incidence of poverty within a state may cause some to resort to criminal activity. Unsatisfied economic aspirations are commonly cited as basic causes of property crimes, such as burglary and theft (Sharp et al., 2000). In the standard literature, criminals are assumed as rational welfare maximizers who compare the risk and the return of indulging in criminal behavior. If the relative attractiveness of illegal pursuits increases so too will the rational offender's allocation of time to crime. Since high unemployment enhances the attractiveness of illegitimate activities, a logical connection between crime and unemployment would arise. Therefore, periods of economic expansions will be associated with a slowing in the growth of crime, while recessions are expected to be associated with an increase in crime. ${ }^{1}$

A large number of studies confirm that, compared to the wealthy, the economically disadvantaged are more likely to commit street crimes of every type (Lafree 1998). Vieraitis (2000) conducted a literature review on 45 studies related to income inequality, poverty, and violent crime. Overall, the majority of studies found positive results for poverty (79\%) on homicide. More than half of the positive results for poverty (66\%) were statistically significant. The relationship between poverty and homicide was significant and positive in $18 / 34$ or $53 \%$ of reported analyses, with non-significant results for $9 / 34$ or $26 \%$ and 4 negative, significant results.

Another economic determinant of crime frequently mentioned in the literature is the real gross state product. Crime theory suggests that criminal activity and specially property crimes increases and decreases with industrial expansion and contraction, whereby crime rates increase during downturns and decrease in periods of good economic conditions. Furthermore, the wealthier the state in any given period, the easier it accommodates demands for public spending than periods of economic crisis. In times of budget crunches states may restrict expenditure on criminal justice to meet the demand for other more deserving public goods.

\footnotetext{
${ }^{1}$ For a detailed explanation of the relationship between crime and unemployment, see Spoon and Holleran (2000), Myers and Sabol (1987a), Wallace (1981), Greenberg (1977), and Blumstein and Cohen (1973).
} 
Some studies also suggest that gross state product may have a positive relationship with crime. A higher gross state product means that there is prosperity and multiple items that are attractive to steal (Cohen \& Felson 1979, Cohen, Felson \& Land 1980). According to the choice theory, rational individuals commit crimes when they believe the benefits of the criminal act outweigh the risks (Senna \& Siegel 1998). This explains why an increase in the amount of "stealable" property is usually followed by an increase in property crimes (Witt, Clarke, and Fielding 1999).

An important fiscal variable usually cited in the literature as negatively correlated with crime is the educational expenditures per pupil. The hypothesis suggests that criminal behavior is associated with poor academic performance (Maguin and Loeber 1996). The quality of education an individual receives will likely affect their ability to achieve personal goals and objectives in the future. Furthermore, schools provide an environment of social interaction where students learn through behavioral conditioning, social modeling, and interaction, and a person's values and self-identity are shaped by their experiences in school. Schools, like families, can discourage crime by reducing criminal motivation, increasing the effectiveness of social control, and in principle at least, by protecting students from the criminal behavior of others. There is also evidence that juveniles who accept the legitimacy of education and who have high educational aspirations and long term education goals are less likely to engage in delinquency (Lafree 1998). Advanced education leads to an ability to earn higher incomes and low educational achievement puts young males at risk of frequent periods of unemployment and of obtaining only low paying and unsatisfactory jobs. Therefore, low educational achievement will be associated with high crime involvement (Ambrosio and Schiraldi 1997, and Bushway and Reuter 1997).

Two more fiscal variable also cited in the literature are welfare expenditure and the expenditure on criminal justice and crime prevention activities. Increases in expenditure on criminal justice are expected to deter criminal behavior. Criminals commit crimes if there is less chance that they will be caught, prosecuted and placed in prison. Welfare expenditures can be thought of as reducing the pain from unemployment and reducing the net return of crime (Besci 1999). Historically, welfare benefits were instituted as alternatives to penal institutions for poor and marginalized populations (Garland 1985, Sutton 1987, and 1990). However, the ready access to a lifetime of welfare and free social service programs is believed to be a major contributory factor to the crime problems in society today (Wright, Green, and Warren 1994). In areas where there are a large amount of welfare payments, there may be a short supply of male role models. This leads to crime in two ways: First, a child whose parents depend on welfare without going to work does not understand that in this society at least one parent is expected to go to work on a daily basis and earn a living. Second, boys growing up in mother only families naturally seek male influences. Those who lack male guidance and companionship may end up in the company of gangs or other undesirable influences (Blankenhorn 1995).

\section{Climatic, Social, and Political Variables}

An important climatic factor usually related to the incidence of crime is the weather temperature. The correlation between temperatures and crime rate are assumed to be positive. In the United States, the regions with the highest crime rates are the southern and western regions and both are known for high temperatures. Crime has consistently been shown to annually peak in the summer months, the hottest time of the year (Senna \& Siegel 1998). This may be due to factors considered in the frustration aggression hypothesis because heat can cause irritability. Furthermore, during higher temperatures people spend more time outside the home. Time spent outside the home, in line with routine activity explanations for crime, has been shown to increase the risk of criminal victimization for most types of crime (Field 1992). An analysis of annual, quarterly, and monthly data for recorded crime in England and Wales yielded strong evidence that temperature has a positive effect on most types of property and violent crimes. The effect was independent of seasonal variation. Field (1992) found that personal crime, including violence against the person and sexual offenses, displayed a strong seasonal pattern, with summer peaks and lower rates in the winter.

An important social factor that is considered in the literature and assumed to be a relevant determinant of crime is the percentage of the population born out of wedlock. This variable is used to measure the lack of parental self-control. Mothers who must provide support and discipline without help from fathers will face greater difficulties meeting these needs (McLanahan and Sandefur 1994). The mothers of children born out of wedlock are 
not as likely to have the resources to keep their children away from hazards. Sampson (1987) provides evidence that family breakdowns lead to serious crimes. It is theorized that out of wedlock births lead to poverty, welfare dependency, and an increased risk of juvenile offending for the children born to unwed mothers. According to McLanahan and Sandefur (1994), unwed mothers have a harder time providing support and discipline than mothers who have fathers present.

A study done by Conseur, Frederick, Barnoski, and Emanuel (1997) matched birth certificates from 1974-1975 to juvenile crime data for 1984-1993 in Washington State. The authors were interested in examining maternal age, maternal marital status when the child was born, gestational age, and birth weight. Conseur et al. found that the mother's marital status and age when the child was born were related to juvenile delinquency for both males and females. Males born out of wedlock were 1.7 times more likely to become a juvenile offender and 2.1 times more likely to become a chronic offender than the males born to married mothers. Males born to young mothers (under 18) were 2.4 times more likely to become an offender and 3.8 times more likely to be a chronic offender, compared to males born to older mothers.

Another equally important social variable related to criminal behavior is the alcohol consumption per capita. A study by Cook and Moore (1993a) suggest that people who have just consumed alcohol commit a disproportionately large number of crimes. Cooke and Moore (1993b) found that alcohol availability increases alcohol consumption, which then increases violence in the United States. Parker (1993) reports that, all things being equal, more murders occur in neighborhoods with high alcohol consumption than in low consumption neighborhoods. Greenfeld (1998) reports that $40 \%$ of all violent offenders in jail reported using alcohol before committing their crimes. A large number of victims also report using alcohol at the time of their victimization (Gyimah-Brempong, 2001). ${ }^{2}$

The political variable believed to be a significant determinant of crime is the party of the governor. Since the Presidential election of 1964, Republican candidates for public office have criticized their Democratic opponents for being "soft on crime" and have called for harsher punishment. National imprisonment rates have grown faster during Republican presidencies (Jacobs and Helms 1996). Although Republican candidates made crime an important issue in their campaigns, conservative Southern Democrats have also backed strong crime control measures. An emphasis on punishment fits with Republican beliefs about individual responsibility. It has been widely alleged as well that law and order appeals allow Republicans to covertly invoke anti-minority sentiments and thereby capture additional blue-collar, lower middle class, and Southern votes. We introduce a measure of party affiliation and examine the influence of office holder's party affiliation at the state level.

\section{THE REGRESSION RESULTS}

Table 1 is a correlation matrix of crime rate and the demographic variables that will be included in the regression equations. The demographic variables are the percent of population in Virginia that is black, population density, the Virginia population in the 15 to 19 and 20 to 24 age groups. All the demographic variables are positively correlated with crime rate. The highest correlation is between crime rate and the 15-19 age-groups, and the lowest correlation is between crime rate and the 20-24 age group.

Table 2 is a correlation matrix of crime and economic and fiscal variables. The variables included are standard in the literature and are commonly believed to be important determinants of crime. The correlation between total crime rate and poverty rate is 0.544 . As Table 2 also indicates, the correlation between real gross state product and crime rate is -0.583 . It also shows a strong negative correlation between crime rate and expenditure per pupil. Table 2 also illustrates a positive and a high correlation between expenditure on criminal justice and crime rate. The correlation between welfare (WELFARE) and total crime rate is positive with a correlation coefficient of 0.634. The correlation between unemployment and crime rate is positive with a partial correlation coefficient of 0.73 .

\footnotetext{
${ }^{2}$ For a criminological and sociological explanations of the correlation between alcohol and crime rate, see Homel, Tomsen, \& Thommeny (1992), Stitt \& Giacopassi (1992), Parker (1993, 1995), Van Oers \& Garretsen (1993), Blount, Silverman, Sellers, \& Seese (1994), Scribner, MacKinnon, \& Dwyer (1995), Roizon (1997), and Scribner, Cohen, Kaplan, \& Allen (1999).
} 
Table 3 presents the correlation matrix of crime rate and social, political, and climatic variables. The correlation between temperature and crime rate is positive although the correlation coefficient is relatively low. Similarly, the correlation between crime rate and summer temperature is positive with a partial correlation coefficient of 0.32 . As Table 4 also indicates the correlation between out of wedlock births and crime rate is positive with a partial correlation coefficient of 0.643 . The correlation between crime rate and alcohol consumption per capita is positive with a correlation coefficient of 0.754 . The correlation between the party of the governor and crime rate is positive with a very small correlation coefficient of 0.151 . It seems that either more crimes are committed in Virginia during Republican administrations or more crimes are reported during Republican tenure in office.

Table 4 contains the regression results. All the variables are differenced to remove the potentially spurious effects of shared trends. If the variables are left in level form, the estimates are extremely unstable due to substantial inter-correlations between explanatory variables. However, as long as both the dependent variable and all the regressors are first differenced, a significant coefficient on an explanatory variable has the same interpretation as it would if the data were in level form.

We tested the presence of multicollinearity among the explanatory variables of the three regression equations. A novel approach of testing multicollinearity is to use "Variance inflationary Factor or VIF." For example $\mathrm{VIF}_{\mathrm{j}}=1 /\left(1-\mathrm{R}_{\mathrm{j}}^{2}\right)$ whereby $\mathrm{R}_{\mathrm{j}}^{2}$ is the coefficient of determination of regression $\mathrm{X}_{\mathrm{j}}$ on all other explanatory variables. If $\mathrm{VIF}_{\mathrm{j}}>5, \mathrm{X}_{\mathrm{j}}$ is highly correlated with other explanatory variables. ${ }^{3}$ All the VIFs were less than 3. Since none of the VIFs exceeded 5, we proceeded using the ordinary least-squares regressions.

The specification in Model 1 include total crime rate as the dependent variable. The coefficients of alcohol consumption per capita (ALCONPC), expenditures on education per pupil (EDUEXPEN), gross real state product (GSPREAL), poverty rate (POVERATE), number of people on welfare (WELFARE), and the number of children born out of wedlock (UNWDBIR) are all significant with the expected sign. The coefficients of crime prone age groups 15-19 (AGE15T19) and 20-24 (AGE20T24) are positive as expected but statistically insignificant. Similarly, the coefficients of the expenditure on criminal justice (CJEXPEND), percent of black population in Virginia (PERBLCKP), unemployment rate (UNEMPRAT), and annual mean temperatures (TEMPERAT) are all positive as expected but are statistically insignificant at the conventional level. The coefficient of population density (DENSITY) exhibits an unexpected negative sign but is also statistically insignificant. The coefficient of the political variable (GOVERNOR) is positive but statistically insignificant.

Model 2 exhibits the regression results when property crime rate is used as the dependent variable. The results in this model are similar to those in Model 1 except the coefficient of the alcohol consumption per capita which remained positive but became statistically insignificant. The coefficient of population density became modestly significant but with still a counterintuitive negative sign.

Model 3 uses violent crime rate as the dependent variable. Again, most of the coefficients of the explanatory variables are similar to those of Model 1 with the coefficients of alcohol consumption per capita, poverty rate, the number of people on welfare, and the number of children in Virginia born out of wedlock showing the expected positive sign and are statistically significant at the 5 percent level. The coefficients of expenditure on education per pupil and real gross state product are significant with the expected negative sign. The rest of the coefficients included in the model are statistically insignificant. Again the coefficient of population density exhibits the unexpected negative sign but statistically insignificant. In this model the political variable (GOVERNOR) became significant. However, the statistical significance of this dummy variable should be interpreted with caution. It is not clear whether more violent crimes are committed when Republicans are in power in Virginia or whether more crimes are reported during Republican administrations because of their emphasis on crime and safety.

\footnotetext{
${ }^{3}$ For a detailed description of VIF, see Marquqardt (1980).
} 


\section{CONCLUDING REMARKS}

The reported crime rate in Virginia has increased more than eighty percent since 1980 and the inmate population in Virginia has also more than doubled since 1989. This phenomenal growth of crime and the prison population, can be adequately explained with the available data. This paper tries to identify the determinants of crime in Virginia using parsimonious regression equations and examines the extent to which those factors such as educational expenditure per pupil, alcohol consumption per capita, expenditure on criminal justice, population density, gross real state product, poverty rate, unemployment rate, and a host of other variables might explain the growth of crime rate in Virginia. When the determinants of crime are clearly identified, appropriate policy conclusions can then be drawn from the analysis, and the policy makers can then design and implement measures to curb and control this unnecessary growth of crime rate.

The results from the regression equations suggest that efforts should be directed to the establishment of good education system. The results indicate that increases on the expenditure on education will decrease the incidence of criminal behavior. Likewise, the results indicate that increases of the expenditure on criminal justice such law enforcement has no significant impact on criminal activity. The results also suggest that the higher the level of economic activity of the state and the lower the level of poverty rate and welfare, the lesser the rate of criminal activity. The results also point out that family breakdowns and the prevalence of out of wedlock births will lead to increases in crime rate. Therefore the role of social institutions such churches is of paramount importance. The results also indicate that social vices such as alcohol consumption contribute to the incidence of criminal behavior. The results also show that the political orientation of the state leader has no bearing on crime rate. Although the empirical results of this paper clarify the relative importance of the determinants of crime, further analysis is needed to confirm the robustness of these results.

Table 1: Correlation Matrix Crime Rate and Demographic Variables

\begin{tabular}{|l|c|c|c|c|c|}
\hline & CRIME & \% BLACK & DENSITY & AGE 15T19 & AGE 20T24 \\
\hline CRIME & 1.000000 & & & & \\
\hline \%BLACK & 0.797435 & 1.000000 & & & \\
\hline DENSITY & 0.689326 & 0.875255 & 1.000000 & & \\
\hline AGE15T19 & 0.879821 & 0.765336 & 0.349731 & 1.000000 & \\
\hline AGE20T24 & 0.649080 & 0.578111 & 0.448485 & 0.452258 & 1.000000 \\
\hline
\end{tabular}

Explanatory Note: CRIME= Crime rates reported per 100,000 population, \% BLACK $=$ Percent of population in Virginia that is black, DENSITY = Population density in Virginia, AGE15T19= Virginia population of 15-19 year olds according to census estimates. AGE20T24= Virginia population of 20-24 year olds according to census estimates.

Table 2: Correlation Matrix Crime Rate and Economic and Fiscal Variables

\begin{tabular}{|l|c|c|c|c|c|c|c|}
\hline & CRIME & CJEXPEND & EDUEXPEN & GSPREAL & POVERATE & TANF & U-RATE \\
\hline CRIME & 1.0000 & & & & & & \\
\hline CJEXPEND & 0.8673 & 1.000 & & & & & \\
\hline EDUEXPEN & $(-0.54)$ & 0.97 & 1.00 & & & & \\
\hline GSPREAL & -0.5830 & 0.99 & 0.99 & 1.00 & & & \\
\hline POVERATE & 0.5442 & 0.60 & 0.50 & 0.55 & 1.00 & & \\
\hline WELFARE & 0.6342 & 0.25 & 0.26 & 0.23 & $(0.13)$ & 1.00 & \\
\hline UNEMPRAT & 0.7321 & $(0.54)$ & $(0.53)$ & $(0.58)$ & $(0.31)$ & 0.28 & 1.00 \\
\hline
\end{tabular}

CRIME= Crime rates reported per 100,000 population, CJEXPEND $=$ Criminal Justice Expenditure, EDUEXPEN $=$ Expenditure per Pupil, GSPREAL $=$ Real Gross State Product, POVERATE $=$ Poverty Rate, WELFARE = Number of People in Virginia Receiving Financial Assistance, UNEMPRAT = Unemployment Rate, 
Table 3: Correlation Matrix of Crime Rate and Social, Political, and Climatic Variables

\begin{tabular}{|l|c|c|c|c|c|c|}
\hline & CRIME & ALCONSPC & TEMPERAT & TEMPSUMR & UNWDBIR & GOVERNOR \\
\hline CRIME & 1.00 & & & & & \\
\hline ALCONSPC & 0.754 & 1.00 & & & & \\
\hline TEMPERAT & 0.164 & $(0.15)$ & 1.00 & & & \\
\hline TEMPSUMR & 0.321 & 0.03 & $(0.18)$ & 1.00 & & \\
\hline UNWDBIR & 0.643 & $(0.91)$ & 0.35 & 0.02 & 1.00 & \\
\hline GOVERNOR & 0.151 & $(0.01)$ & $(0.11)$ & 0.07 & $(0.22)$ & 1.00 \\
\hline
\end{tabular}

CRIME $=$ Crime rates reported per 100,000 population, ALCONSPC $=$ Alcohol consumption per capita, TEMPERAT $=$ Annual temperature, TEMPSUMR $=$ Summer temperature, UNWDBIR $=$ Out of wedlock births, Governor $=$ The party of the governor.

Table 4: Regression Results of the Determinants of Crime in Virginia

\begin{tabular}{|c|c|c|c|}
\hline Explanatory Variables & Crime & Property & Violent \\
\hline CONSTANT & $\begin{array}{c}-0.0566 \\
(1.1134)\end{array}$ & $\begin{array}{c}-0.0981 \\
(1.0934)\end{array}$ & $\begin{array}{c}-0.1064 \\
(-1.5671)\end{array}$ \\
\hline ALCONSPC & $\begin{array}{l}0.654 \\
(6.28)\end{array}$ & $\begin{array}{l}0.0051 \\
(1.006)\end{array}$ & $\begin{array}{l}2148.3 \\
(4.313)\end{array}$ \\
\hline CJEXPEND & $\begin{array}{l}-0.0671 \\
(-1.234)\end{array}$ & $\begin{array}{l}-0.0589 \\
(-1.067)\end{array}$ & $\begin{array}{l}-0.3241 \\
(-1.543)\end{array}$ \\
\hline DENSITY & $\begin{array}{c}-3.010 \\
(-1.098)\end{array}$ & $\begin{array}{c}-2.51 \\
(-1.68)\end{array}$ & $\begin{array}{c}-1.817 \\
(-1.532)\end{array}$ \\
\hline EDUEXPEN & $\begin{array}{c}-3.794 \\
(-3.145)\end{array}$ & $\begin{array}{c}-3.867 \\
(-2.964)\end{array}$ & $\begin{array}{l}-0.8940 \\
(-3.271)\end{array}$ \\
\hline GSPREAL & $\begin{array}{l}-0.5377 \\
(-5.312)\end{array}$ & $\begin{array}{l}-0.7783 \\
(-4.832)\end{array}$ & $\begin{array}{l}-0.4132 \\
(-3.792)\end{array}$ \\
\hline PERBLCKP & $\begin{array}{l}0.0854 \\
(1.369)\end{array}$ & $\begin{array}{l}0.0932 \\
(1.087)\end{array}$ & $\begin{array}{l}0.0777 \\
(1.149)\end{array}$ \\
\hline POVERATE & $\begin{array}{l}1.8003 \\
(7.975)\end{array}$ & $\begin{array}{c}2.103 \\
(8.334)\end{array}$ & $\begin{array}{l}1.1493 \\
(6.987)\end{array}$ \\
\hline WELFARE & $\begin{array}{l}0.1444 \\
(2.133)\end{array}$ & $\begin{array}{l}0.1276 \\
(3.554)\end{array}$ & $\begin{array}{l}0.1245 \\
(1.982)\end{array}$ \\
\hline TEMPERAT & $\begin{array}{l}3.6124 \\
(1.319)\end{array}$ & $\begin{array}{c}4.410 \\
(1.077)\end{array}$ & $\begin{array}{l}3.1321 \\
(1.149)\end{array}$ \\
\hline UNEMPRAT & $\begin{array}{l}0.0321 \\
(0.052)\end{array}$ & $\begin{array}{l}0.0542 \\
(0.921)\end{array}$ & $\begin{array}{l}0.3210 \\
(1.532)\end{array}$ \\
\hline UNWDBIR & $\begin{array}{l}0.6341 \\
(3.794)\end{array}$ & $\begin{array}{c}0.214 \\
(3.151)\end{array}$ & $\begin{array}{l}0.2999 \\
(3.890)\end{array}$ \\
\hline AGE15T19 & $\begin{array}{l}0.0651 \\
(1.012)\end{array}$ & $\begin{array}{l}0.0341 \\
(1.445)\end{array}$ & $\begin{array}{l}0.0543 \\
(1.229)\end{array}$ \\
\hline AGE20T24 & $\begin{array}{l}0.0771 \\
(1.379)\end{array}$ & $\begin{array}{c}0.09231 \\
(1.0051)\end{array}$ & $\begin{array}{l}0.0882 \\
(1.463)\end{array}$ \\
\hline GOVERNOR & $\begin{array}{l}0.0113 \\
(1.034)\end{array}$ & $\begin{array}{l}0.1443 \\
(0.987)\end{array}$ & $\begin{array}{l}0.0834 \\
(1.984)\end{array}$ \\
\hline Method Of Estimation & OLS & OLS & OLS \\
\hline Adjusted R-Square & 0.7632 & 0.6721 & 0.6441 \\
\hline
\end{tabular}

DEPENDENT VARIABLES: CRIME= Crime rates reported per 100,000 population, PROPERTY: Property crime rates reported per 100,000 population, VIOLENT: Violent crime rates reported per 100,000 population.

EXPLANATORY VARIABLES: ALCONSPC = Alcohol Consumption per Capita, CJEXPEND = Expenditure on Criminal Justice, EDUEXPEN = Expenditure per Pupil, DENSITY = Population Density in Virginia, GSPREAL = Real Gross State Product, PERBLCKP = Percent of Black Population in Virginia, POVERTY RATE $=$ Percent of 
People Below Poverty Line as Decided by Census, WELFARE = Number of Persons in VA Receiving Financial Assistance, TEMPERAT $=$ Mean Annual Temperature, UNEMPRAT $=$ Unemployment Rate per Individual in VA, Seasonally Adjusted, UNWDBIR= Number of Children Born Out of Wedlock in VA. AGE15T19= Virginia population of 15-19 year olds according to census estimates. AGE20T24= Virginia population of 20-24 year olds according to census estimates.

\section{REFERENCE}

1. Ambrosio, T., \& V. Schiraldi, 1997 From Classrooms to Cellblocks: A National Perspective [On-line], Available: http://www.cjcj.org/jpi/highernational.html.

2. Arvanites, Thomas M., 1993 Increasing Imprisonment: a Function of Crime or Socio- Economic Factors, American Journal of Criminal Justice, 17:19-38.

3. - - -

Variables on State Imprisonment Rates, Criminal Justice Policy Review, 7:27-53.

4. Beckett, Katharine \& Bruce Western, 2001 Governing Social Marginality: Welfare, Incarceration, and the Transformation of State Policy, Punishment and Society, 3:43-59.

5. Beckett, Katharine \& Bruce Western, 2000 The Politics of Injustice: Crime and Punishment in America (Thousand Oaks, CA: Pine Forge).

6. Becsi, Z., 1999 Economics and Crime in the States, Economic Review [On-line), Available: http://www.frbatlanta.org/publica/eco-rev/rev abs/99er/q1/zbesci.pdf.

7. Blackenhorn, D., 1995 Fatherless America: Confronting Our Most Urgent Social Problem (New York: Basic Books).

8. Blount, W. R., I. J. Silverman, C. S. Sellers, \& R. A. Seese, 1994 Alcohol and Drug Use Among Abused Women Who kill, Abused Women Who Don't, and Their Abusers, Journal of Drug Issues, 24:165-77.

9. Blumstein, A., 1998 U.S. Criminal Justice Conundrum: Rising Prison Populations and Stable Crime Rates, Crime and Delinquency, 44:127-36.

10. $\quad$---actine Cohen, 1973 A Theory of the Stability of Punishment, Journal of Criminal Law and Criminology, 64:198-207.

11. Braithwaite, J., 1989 Crime, Shame and Reintegration (New York: Cambridge Press).

12. Brenner, M. Harvey, 1976 Time Series Analysis: Effects of the Economy on Criminal Behavior and the Administration of Criminal Justice, In Economic Crises and Crime (Rome: UN Social Defense Research Institute, Publication \#15)

13. Bushway, S. D., and P. Reuter, 1997 Labor Markets and Crime Risk Factors, In L.W. Sherman, D. Gottfredson, D. Mackenzie, P. Reuter, J. Eck, and S. Bushway (Eds.), Preventing Crime: What Works, What Doesn't, What's Promising [On-line]. Available: http://www.ncjrs.org/works/chapter6.htm.

14. Carroll, Leo \& Mary Beth Doubet, 1983 US Social Structure and Imprisonment, Criminology, 12:449-556.

15. Cohen, Lawrence C., Marcus Felson, \& Kenneth C. Land, 1980 Property Crime Rates in the United Sates: A Macrodynamic Analysis, 1947-1977, With Ex Ante Forecasts for the Mid-1980s. American Journal of Sociology, 86:90-118.

16. Cohen, Lawrence C., Marcus Felson, \& Kenneth C. Land, 1979 Social Change and Crime Rate Trends: A Routine Activities Approach, American Sociological Review, 44: 588-608

17. - Ecological Approach, American Journal of Sociology, 94:465-501.

18. Colvin, Mark, 1990 Labor markets, Industrial Monopolization, Welfare and Imprisonment: Evidence From a Cross-Section of US Counties, Sociological Quarterly, 31:441-57.

19. Cook, P., and M. Moore, 1993a Violence Reduction Through Restrictions on Alcohol Availability, Alcohol,Health, and Research World, 17:148-54.

20. Conseur, A., P. R. Frederick, R. Barnoski, \& I. Emanuel, 1997 Maternal and Prenatal Risk Factors for Later Delinquency, Pediatrics, 99:785-81.

21. Defronzo, James, 1983 Ecnomic Assistance to Impoverished Americans: Relationship to Incidence of Crime, Criminology, 21: 119-36.

22. Field, Simon, 1992 The Effect of Temperature on Crime, British Journal of Criminology, 32(3): 340-51.

23. Garland, D., 1985 Punishment and Welfare: A History of Penal Strategies (Brookfield, VT: Gower). 
24. Gottfredson, M. A., \& T. Hirschi, 1990 A General Theory of Crime ( Stanford, CA: Stanford University Press).

25. Greenberg, David F., 1977 The Dynamics of Oscillatory Punishment Process, Journal of Criminal Law and Criminology, 68:643-51.

26. Greenfeld, Lawrence A., 1998 Alcohol and Crime: An Analysis of National Data on The Prevalence of Alcohol Involvement in Crime, NCJ, No. 168632.

27. Grimes, P. W., \& K. E. Rogers, 1999 Truth-in-Sentencing, Law Enforcement, and Inmate Population Growth, The Journal of Socio-Economics, 28:746-58.

28. Gyimah-Brempong, K., 2001 Alcohol Availability and Crime: Evidence from Census Tract Data, Southern Economic Journal, 68:2-21.

29. Homel, R., S. Tomsen, \& J. Thommeny, Public Drinking and Violence: Not Just an Alcohol Problem, Journal of Drug Issues, 22, pp:79-97.

30. Jackson, Pamela Irving, 1989 Minority Group Threat, Crime, and Policing: Social Context And Social Control (New York: Praeger).

31. Jacobs, David \& Ronald E. Helms, 1996 Toward a Political Model of Incarceration: A Time-Series Examination of Multiple Explanations for Prison Admission Rates, American Journal of Sociology, 102:323-57.

32. Jacobs, David \& Ronald E. Helms, 1979 Inequality and Police Strength: Conflict Theory and Coercive Control in Metropolitan Areas, American Sociological Review, 46:290-305.

33. Joubert, Paul, J. Steven Picou \& W. Alex McIntosh, 1981 US Social Structure, Crime, and Punishment, Criminology, 19:344-59.

34. Lafree, G., 1998 Social Institutions and the Crime Bust of the 1990s, Journal of Criminal Law and Criminology, 88:1325-45.

35. Lang, A. R., \& P. A. Sibrel, 1989 Psychological Perspectives on Alcohol Consumption and Interpersonal Aggression: The Potential Role of Individual Differences in Alcohol-related Criminal Violence, Criminal Justice and Behavior, 16:299-324.

36. Maguin, E., and R. Loeber, 1996 Academic Performance and Delinquency, In M. Tonry, and D. Farrington (Eds.), Crime and Justice: An Annual Review of Research, pp:145-264 (Chicago, IL: University of Chicago Press).

37. Marquardt, D. W, 1980 You Should Standardize the Predictor Variables in Your Regression Models, Journal of American Statistical Association, 75:87-91.

38. McLanahan, Sara and Gary Sandefur, 1994 Growing Up With a Single Parent (Cambridge, Mass: Harvard University Press).

39. Myers, Samuel L. \& William J. Sabol, 1987a Business Cycle and Racial Disparities in Punishment, Contemporary Policy Issue, 5:46-58.

40. Parker, R. N., \& L. A., 1995 Alcohol and Homicide: A Deadly Combination of Two American Traditions (New York: State University of New York).

41. Parker, R. N., \& L. A., 1993 Alcohol and Theories of Homicide, In F. Adler and W. Laufer (Eds.), Advances in Criminological Theory, 4:113-142 (Somerset, NJ: Transactions Publishers).

42. Petersilia, Joan, 1983 Racial Disparities in the Criminal Justice System (Santa Monica, CA: The Rand Corporation).

43. Roizon, J., 1997 Epidemiological Issues in Alcohol-related Violence, In M. Galanter, (Ed.), Recent Developments in Alcoholism (New York: Plenum Press).

44. Rotton, J., \& E. O. Cohn, 2000 Weather, Disorderly Conduct, and Assaults: From Social Contact to Social Avoidance, Environment and Behavior, 32:651-73.

45. Rush, B. R., L. Glickman, \& R. Brook, R., 1986 Alcohol Availability, Alcohol Consumption, and Alcoholrelated Damage, I \& II, Journal of Studies on Alcohol, 47:1-18.

46. Sampson, Robert J., 1987 Urban Black Violence: The Effect of Male Joblessness and Family Disruption, American Journal of Sociology, 93:348-82.

47. Scribner, R., D. Cohen, S. Kaplan, \& S. Allen, 1999 Alcohol Availability and Homicide in New Orleans: Conceptual Considerations for Small Area Analysis of the Effect of Alcohol Outlet Density, Journal of Studies on Alcohol, 60:310-16.

48. Scribner, R. A., D. P. MacKinnon, \& J. H. Dwyer, 1995 The Risk of Assaultive Violence and Alcohol Availability in Los Angeles County, American Journal of Public Health, 85:335-338. 
49. Senna, J. J., \& L. J. Siegel, 1998 Essentials of Criminal Justice (New York: Wadsworth).

50. Sharp, A., C. Register, \& P. Grimes, 2000 Economics of Social Issues (San Francisco, CA: Irwin/McGrawHill).

51. Spohn, Cassia, \& David Holleran, 2000 The Imprisonment Penalty Paid by Young, Unemployed Black and Hispanic Male Offenders, Criminology, 38:281-306.

52. Sprunt, B., P. Goldstein, H. Brownstein, M. Fendrich, \& S. Langley, 1994 Alcohol and Homicide: Interviews with Prison Inmates, Journal of Drug Issues, 24:143-63.

53. Stitt, B.G., \& D. J. Giacopassi, 1992 Alcohol Availability and Alcohol-related Crime, Criminal Justice Review, 17:268-279.

54. Stitt, B.G., \& D. J. Giacopassi, 1987 Doing Time: Dynamics of Imprisonment in the Reformist State, American Sociological Review, 52:612-630.

55. Van Oers, J. A., \& H. F. Garretsen, 1993 The Geographic Relationship Between Alcohol Use, Bars, Liquor Shops, and Traffic Injuries in Rotterdam, Journal of Studies on Alcohol, 54:739-744.

56. Vieraitis, L. M., 2000 Income Inequality, Poverty, and Violent Crime: A Review of the Empirical evidence, Social Pathology: A Journal of Reviews, 6:24-45

57. Wallace, Don, 1981 The Political Economy of Incarceration Trends in Late US Capitalism: 1971-77, Insurgent Sociologist, 10:.59-67.

58. Witt, R., A. Clarke, and N. Fielding, 1999 Crime and Economic Activity: A Panel Approach, British Journal of Criminology, 39:391-411.

59. Wright, J. L., M Green, and L. Warren, 1994 An Assessment of Crime in Maryland Today. Maryland State Conference of Branches, NAACP, Executive Summary. 


\section{APPENDIX A: DATA DESCRIPTION AND SOURCES}

Gross State Product (GSPREAL): gross state product in millions. Source: Bureau of Economic Analysis Web site: http://www.bea.doc.gov/bea/regional/gsp/action.cfm

Unemployment Rate (UNEMPRAT) : Unemployment rate per individual in VA, seasonally adjusted. Source: Bureau of labor statistics website: www.bls.gov/lau/home.htm and from Edna Biederman, Economist, biederman_e@bls.gov, (202) 691-6393

Expenditure on Education (EDUEXPEN): dollars expended per pupil. Source: Virginia Department of Education Website www.pen.k12.va.us/VDOE/Publications/asrstat/1999-00/tab15.htm

Expenditure on Criminal Justice (CJEXPEND): expenditures, total justice system, including police, corrections, judicial/legal in thousands of dollars. Source: www.ojp.usdoj.gov/bjs/glance/exptyp.htm. (Sourcebook of Criminal Justice Statistics). The years 1982-1997 are available on the website. The rest were obtained from the print version of the Sourcebook.

Welfare (TANF: ): number of persons in VA receiving financial assistance. Source: www.acf.dhhs.gov/news/stats/caseload.htm and www.acf.dhhs.gov/programs/opre/afdc/afdc.htn Program was called AFDC (Aid to Families with Dependent Children) until 1995, when the organization changed the name of the program to TANF (Temporary Assistance for Needy Families) and changed their criterion.

Poverty Rate (POVERATE): poverty rate, percent of people below poverty line as decided by census. Source: http://www.census.gov/hhes/poverty/histpov/hstpov21.html.

Crime prone age group (AGE15T19): Virginia population of 15-19 year olds according to census estimates. Crime prone age group (AGE20T24): Virginia population of 20-24 year olds according to census estimates Source: Data was taken in 1970, 1980, 1990 and 2000. Those numbers are the actual number of persons in the population at that time. The years in between those census markers are population estimates, seasonally adjusted for the state of Virginia. Projections are available for download for up to 25 years.

Sources: www.census.gov, www.census.gov/population/estimates/state/st-99-08.txt, www.census.gov/population/estimates/state/s5yr8090.txt, and

www.census.gov/population/estimates/state/e7080sta.txt

Crime Rate (CRIME): Violent Crime (VIOLENT) is Part 1 offenses and includes: Murder, Manslaughter, Rape, Robbery, Aggravated Assault, Burglary, Larceny, Motor Vehicle Theft, and Arson. * Property Crimes (PROPERTY) include forgery, and Counterfeiting.

Temperature (TEMPERAT): Mean Annual Temperature. Source: National Climate Data Center at http://lwf.ncdc.noaa.gov/oa/ncdc.html

Alcohol Consumption per Capita (ALCONSPC): Per capita ethanol consumption (in gallons) and is based on alcohol sales data. Sources: National Institute of Health: National Institute on Alcohol Abuse \& Alcoholism, www.niaaa.nih.gov/databases/consum02.txt and VA Department of Alcoholic Beverage Control, www.abc.state.va.us/admin/reports/bevsales/abcscale97.htm. Contact at ABC: Linda Wine, lcwine@ @abc.state.va.us. Ethanol: the main psychoactive ingredients in alcoholic beverages; results from the fermentation of sugar by yeast.

Black Population (PERBLCKP): Percent of Black Population In Virginia; 1970, 1980, 1990, 2000 are actual census numbers, rest are estimates. Source: www.nationalatlas.gov/census1980m.html\#1, www.census.gov.

Out of Wedlock Children (UNWDBIR): Number of children born out of wedlock in VA. Source: VA Department of Health, www.vdh.state.va.us, Betty Essex, bessex@vdh.state.va.us and National Center for Health Statistics, www.cdc.gov/nchs/births.htm\#statebirths. 
NOTES 